\title{
Ewa Dziawgo*
}

\section{WPŁYW PARAMETRU LUKI NA RYZYKO OPCJI SPRZEDAŻY}

\section{Wprowadzenie}

Zjawisko globalizacji procesów gospodarczych stwarza firmom wiele nowych wyzwań i możliwości inwestycyjnych. Jednocześnie wzrost konkurencyjności otoczenia i nasilenie zmienności warunków rynkowych przyczyniają się do poszukiwania nowych rozwiązań w zakresie zarządzania ryzykiem, których umiejętne zastosowanie mogłoby spowodować poprawę wyników finansowych firmy. W wypadku firm prowadzących działalność gospodarczą na rynkach zagranicznych występuje ryzyko niekorzystnej zmiany kursu walutowego. Ważne znaczenie w zarządzaniu ryzykiem zmiany kursu walutowego mają instrumenty pochodne, wśród których szczególnym jest kontrakt opcyjny. Wyjątkowość tego instrumentu wynika z niesymetryczności praw i obowiązków nałożonych na strony transakcji:

- nabywca opcji ma prawo realizacji umowy,

- wystawca opcji jest zobowiązany do wykonania kontraktu, o ile nabywca opcji będzie realizował umowę ${ }^{1}$.

Nabywca opcji dokonuje transferu ryzyka związanego z niekorzystną zmianą ceny instrumentu bazowego w przyszłości. Płaci wystawcy opcji premię. Nabywca opcji sprzedaży ma prawo sprzedaży określonego instrumentu bazowego w określonym czasie ${ }^{2}$ po określonej cenie ${ }^{3}$.

$\mathrm{W}$ analizie kontraktów opcyjnych istotne znaczenie ma rozpatrywanie wartości współczynników: delta, gamma, vega, theta i rho. Są to miary wrażliwości ceny opcji, które określają wpływ czynnika ryzyka na cenę opcji ${ }^{4}$.

* Uniwersytet Mikołaja Kopernika w Toruniu, Wydział Nauk Ekonomicznych i Zarządzania.

1 C.J. Hull, Options, futures and other derivatives, Prentice Hall International Inc., 2002, s. 193; W. Tarczyński, M. Zwolankowski, Inżynieria finansowa, Agencja Wydawnicza Placet, Warszawa 1999, s. 149.

2 Jest to czas wykonania opcji.

3 Jest to cena wykonania opcji.

4 E. Dziawgo, Modele kontraktów opcyjnych, Wydawnictwo Naukowe UMK, Toruń 2003, s. 103; P. Willmot, Derivatives. The Theory and Practice of Financial Engineering, John Wiley \& Sons, Chichester 2000, s. 91. 
Opcje z odstępem (gap options) należą do klasy opcji pojedynczych, które charakteryzują się nieciągłością funkcji wypłaty.

W artykule przedstawiono własności opcji sprzedaży z odstępem: funkcję wypłaty, model wyceny, wpływ parametru luki, ceny instrumentu bazowego oraz terminu wygaśnięcia na kształtowanie się ceny opcji oraz wartości miar ryzyka.

Celem artykułu jest przedstawienie wpływu wartości parametru luki na ryzyko opcji sprzedaży. Analiza empiryczna przedstawiona w artykule przeprowadzona jest na podstawie symulacji wyceny opcji walutowych wystawionych na EUR/PLN.

\section{Własności opcji sprzedaży z odstępem}

Funkcja wypłaty opcji z odstępem powstaje wskutek wprowadzenia do funkcji wartości końcowej opcji zwykłej parametru luki ${ }^{5}$. Jeżeli opcja sprzedaży z odstępem wygasa $w$-cenie, to wartość wypłaty nabywcy opcji jest równa wartości wypłaty ze zwykłej opcji sprzedaży pomniejszonej o parametr luki'.

Funkcja wypłaty opcji sprzedaży z odstępem określona jest równaniem:

$$
F_{T}=Y-S_{T} \|_{S_{T}<K}
$$

gdzie:

$F_{T}$ - funkcja wypłaty opcji sprzedaży z odstępem, $Y=K-L, K$ - cena wykonania, $L$ - parametr luki, $S_{T}$ - cena instrumentu bazowego w chwili $T, T$-czas wygaśnięcia.

Model wyceny opcji sprzedaży z odstępem wyrażony jest równaniem:

$$
p_{t}=Y e^{-r(T-t)} N\left(-d_{2}\right)-S_{t} e^{-q(T-t)} N\left(-d_{1}\right)
$$

gdzie:

$p_{t}$ - cena opcji sprzedaży z odstępem, $N(d)$ - dystrybuanta rozkładu normalnego zmiennej $d, r$-stopa procentowa wolna od ryzyka, $\sigma$-zmienność ceny instrumentu

5 P.G. Zhang, Exotic Options. A Guide to Second Generation Options, Word Scientific, Singapore 2001, s. 116; A. Napiórkowski, Charakterystyka, wycena i zastosowanie wybranych opcji egzotycznych, NBP Departament Analiz i Badań, Warszawa 2002, s. 30.

6 Opcja sprzedaży jest typu $w$-cenie/nie-w-cenie, gdy cena instrumentu bazowego jest mniejsza/większa od ceny wykonania. Jeśli cena instrumentu bazowego jest równa cenie wykonania, to opcja sprzedaży jest typu po-cenie. 
bazowego, $S_{t}$ - cena instrumentu bazowego w chwili $t, t \in[0 ; T], q-$ stopa dywidendy $\mathrm{z}$ instrumentu bazowego ${ }^{7}$,

$$
d_{1}=\frac{\ln \frac{S_{t}}{K}+\left(r-q+0,5 \sigma^{2}\right)(T-t)}{\sigma \sqrt{T-t}}, d_{2}=d_{1}-\sigma \sqrt{T-t}
$$

pozostałe oznaczenia są takie same jak we wzorze (1).

Rysunek 1 przedstawia kształtowanie się ceny zwykłej opcji sprzedaży oraz opcji sprzedaży z odstępem. Opcje wystawione są na EUR/PLN. Termin wygaśnięcia opcji wynosi 3 miesiące. Symulacja wyceny przeprowadzona jest dla okresu 02.02.2015-30.04 .2015 r. Cena wykonania opcji wynosi 4,15 PLN. Analizowane opcje były $w$-cenie w okresie: 02.03.2015 r., 06.03.2015-13.03.2015 r., 17.03.2015-30.04.2015 r. $\mathrm{W}$ pozostałym rozpatrywanym okresie opcje były nie-w-cenie. Analiza przeprowadzona jest dla opcji sprzedaży z dodatnią i ujemną wartością parametru luki oraz dla zwykłej opcji sprzedaży ${ }^{8}$. W tabeli 1 przedstawiono wpływ parametru luki oraz terminu wygaśnięcia na cenę opcji sprzedaży.

Rysunek1. Kształtowanie się ceny zwykłej opcji sprzedaży oraz opcji sprzedaży z odstępem

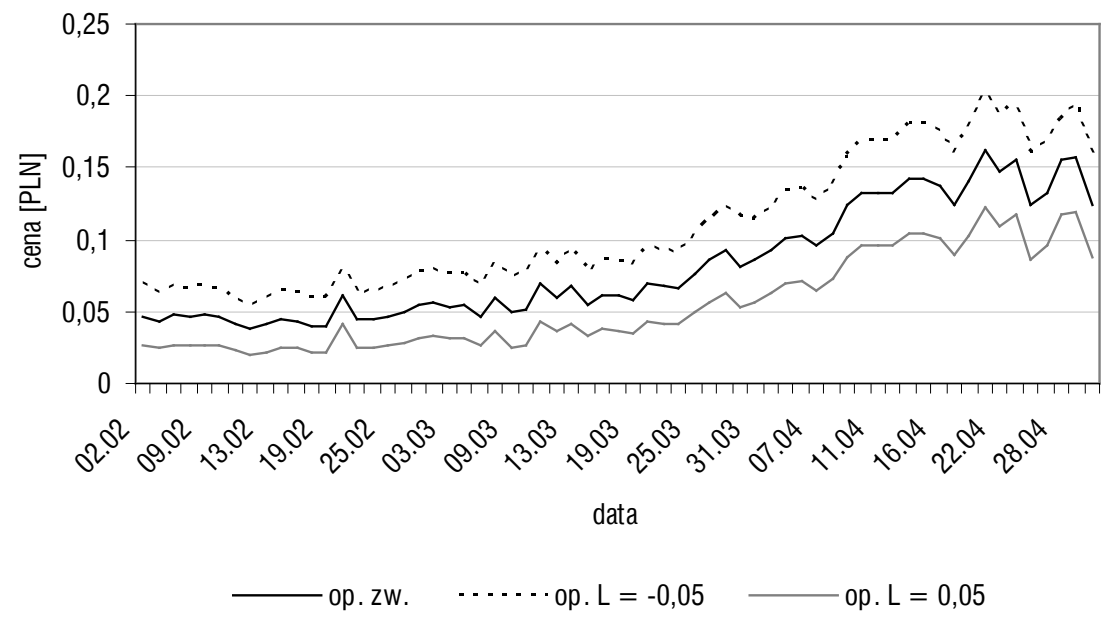

Źródło: Opracowanie na podstawie obliczeń własnych.

7 W wypadku opcji walutowych $r$ jest krajową stopą procentową wolną od ryzyka, natomiast $q$ jest stopą procentową wolną od ryzyka w kraju waluty obcej, na którą wystawiono opcję.

8 Parametr luki zwykłej opcji sprzedaży wynosi zero. 
Tabela 1. Wpływ parametru luki oraz terminu wygaśnięcia na cenę opcji sprzedaży $z$ odstępem

\begin{tabular}{|c|c|c|c|c|}
\hline \multirow{2}{*}{ Wartość luki } & \multirow{2}{*}{$\begin{array}{l}\text { Czas wygaśnięcia } \\
\text { (w miesiącach) }\end{array}$} & \multicolumn{3}{|c|}{ Typ орсіi } \\
\hline & & nie-w-cenie & po-cenie & w-cenie \\
\hline \multirow{3}{*}{$-0,05$} & 2 & 0,0231 & 0,063 & 0,1421 \\
\hline & 4 & 0,0487 & 0,0723 & 0,1551 \\
\hline & 6 & 0,0597 & 0,0854 & 0,1634 \\
\hline \multirow{3}{*}{0} & 2 & 0,0123 & 0,0596 & 0,1035 \\
\hline & 4 & 0,0352 & 0,0668 & 0,1228 \\
\hline & 6 & 0,0451 & 0,0705 & 0,1336 \\
\hline \multirow{3}{*}{0,05} & 2 & 0,0015 & 0,0351 & 0,0668 \\
\hline & 4 & 0,0217 & 0,0397 & 0,0905 \\
\hline & 6 & 0,0305 & 0,0416 & 0,1037 \\
\hline
\end{tabular}

Źródło: Obliczenia własne.

$\mathrm{Z}$ analizy kształtowania się cen wynikają następujące własności opcji sprzedaży z odstępem:

- opcja z dodatnią/ujemną wartością parametru luki jest tańsza/droższa od zwykłej opcji sprzedaży,

- zarówno w wypadku dodatniej, jak i ujemnej wartości parametru luki:

- wzrost/spadek ceny instrumentu bazowego wpływa na spadek/wzrost ceny opcji,

- opcje z dłuższym terminem wygaśnięcia są droższe.

\section{Wrażliwość ceny opcji sprzedaży z odstępem}

\subsection{Współczynnik delta}

Współczynnik delta określa, o ile zmieni się cena opcji, jeśli cena instrumentu bazowego zmieni się o jednostkę. Wartości współczynnika delta zwykłej opcji sprzedaży są ujemne. Oznacza to, że wzrost/spadek ceny instrumentu bazowego wpływa na spadek/wzrost ceny opcji. Wartości współczynnika delta opcji sprzedaży są zawarte w przedziale $[-1 ; 0]$. W wypadku opcji sprzedaży typu $w$-cenie wartości współczynnika delta zmierzają do -1. Natomiast wartości współczynnika delta opcji sprzedaży typu nie-w-cenie wzrastają do 0 . Cena opcji sprzedaży silnie-nie-w-cenie w niewielkim stopniu zmienia się wraz ze zmianą ceny instrumentu bazowego.

Rysunek 2 ilustruje kształtowanie się wartości współczynnika delta analizowanych opcji sprzedaży z odstępem. W tabeli 2 przedstawiono wpływ parametru luki 
oraz terminu wygaśnięcia na kształtowanie się wartości współczynnika delta opcji sprzedaży.

Rysunek 2. Kształtowanie się wartości współczynnika delta zwykłej opcji sprzedaży oraz opcji sprzedaży z odstępem

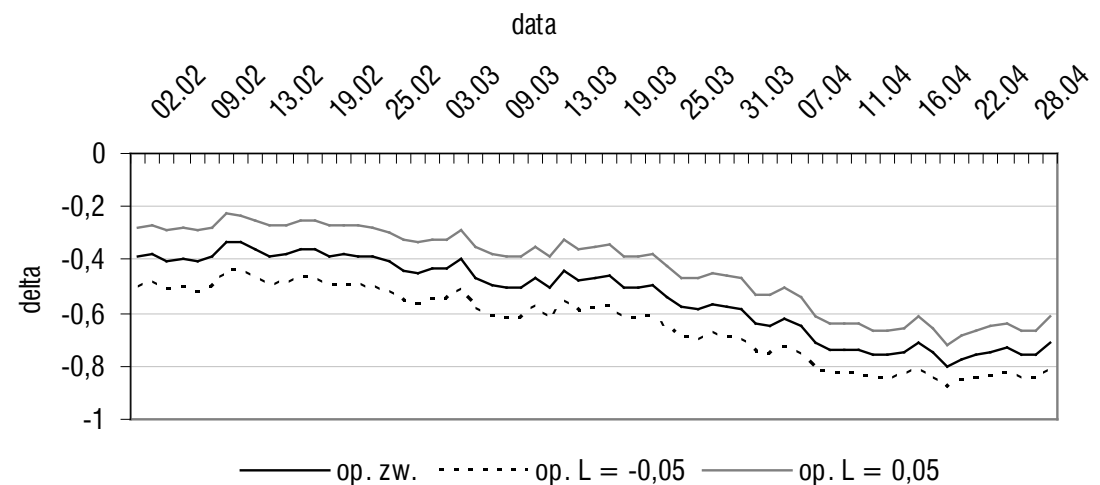

Źródło: Opracowanie na podstawie obliczeń własnych.

Tabela 2. Wpływ parametru luki oraz terminu wygaśnięcia na wartość współczynnika delta opcji sprzedaży z odstępem

\begin{tabular}{|c|c|c|c|c|}
\hline \multirow{2}{*}{ Wartość luki } & $\begin{array}{c}\text { Czas wygaśnięcia } \\
\text { (w miesiącach) }\end{array}$ & nie-w-cenie & po-cenie & w-cenie \\
\cline { 2 - 5 } & 2 & $-0,3114$ & $-0,598$ & $-0,8473$ \\
\hline \multirow{4}{*}{0,05} & 4 & $-0,3395$ & $-0,456$ & $-0,729$ \\
\cline { 2 - 5 } & 6 & $-0,3469$ & $-0,3143$ & $-0,6108$ \\
\hline \multirow{3}{*}{0} & 2 & $-0,209$ & $-0,5403$ & $-0,7318$ \\
\cline { 2 - 5 } & 4 & $-0,2578$ & $-0,4404$ & $-0,6368$ \\
\cline { 2 - 5 } & 6 & $-0,2776$ & $-0,3404$ & $-0,5418$ \\
\hline \multirow{3}{*}{0,05} & 2 & $-0,1065$ & $-0,51$ & $-0,6668$ \\
\cline { 2 - 5 } & 4 & $-0,176$ & $-0,4286$ & $-0,5861$ \\
\cline { 2 - 5 } & 6 & $-0,2082$ & $-0,3471$ & $-0,5053$ \\
\hline
\end{tabular}

Źródło: Obliczenia własne.

Współczynnik delta opcji sprzedaży z odstępem charakteryzuje się następującymi własnościami:

- wzrost wartości parametru luki wpływa na wzrost wartości współczynnika delta, a tym samym na spadek wrażliwości ceny opcji na zmianę ceny instrumentu bazowego,

- zarówno dla dodatniej, jak i ujemnej wartości parametru luki: 
- wzrost/spadek ceny instrumentu bazowego wpływa na wzrost/spadek wartości współczynnika delta,

- opcje typu nie-w-cenie z dłuższym terminem wygaśnięcia odznaczają się mniejszą wartością współczynnika delta,

- opcje typu po-cenie lub $w$-cenie $\mathrm{z}$ dłuższym terminem wygaśnięcia charakteryzują się większą wartością współczynnika delta. W tym wypadku cena opcji charakteryzuje się mniejszą wrażliwością na zmianę ceny instrumentu bazowego.

\subsection{Współczynnik gamma}

Współczynnik gamma określa, jak zmieni się wartość współczynnika delta, gdy cena instrumentu bazowego zmieni się o jednostkę. Współczynnik gamma zwykłej opcji sprzedaży jest dodatni. Oznacza to, że wzrost/spadek ceny instrumentu bazowego wpływa na wzrost/spadek wartości współczynnika delta. Opcja typu po-cenie charakteryzuje się największą wartością współczynnika gamma. W wypadku opcji typu silnie-w-cenie oraz silnie-nie-w-cenie wartości współczynnika gamma zmierzają do zera.

Na rysunku 3 przedstawiono kształtowanie się wartości współczynnika gamma rozpatrywanych opcji sprzedaży.

Rysunek 3. Kształtowanie się wartości współczynnika gamma zwykłej opcji sprzedaży oraz opcji sprzedaży z odstępem

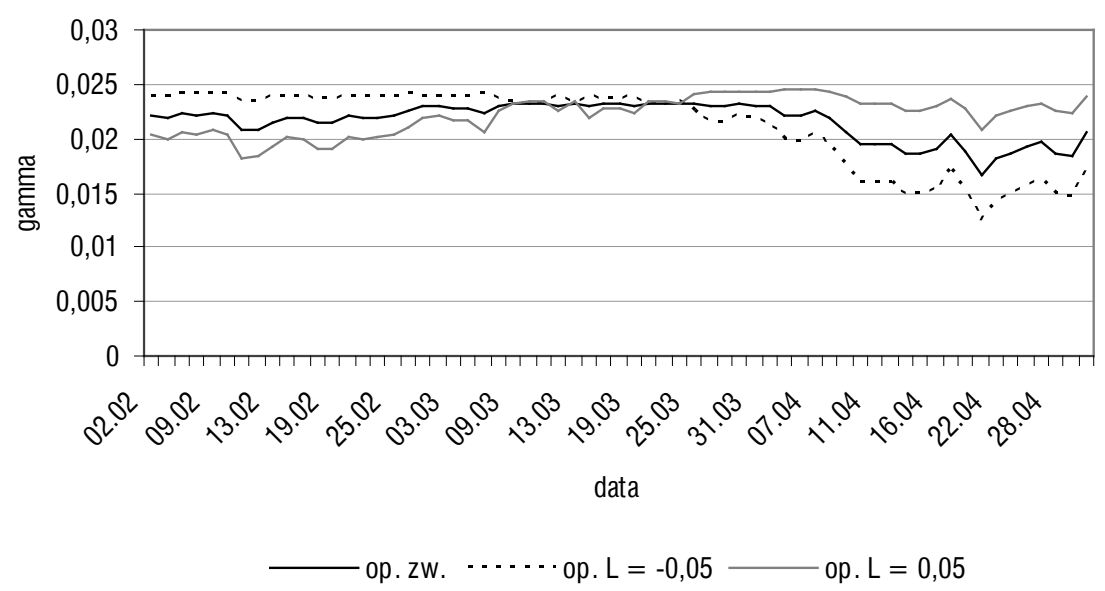

Źródło: Opracowanie na podstawie obliczeń własnych. 
Największa wartość współczynnika gamma występuje, kiedy cena instrumentu bazowego kształtuje się w pobliżu ceny wykonania opcji. Jeśli cena instrumentu bazowego jest mniejsza od ceny wykonania, to wzrost wartości parametru luki wpływa na wzrost wartości współczynnika gamma. Wówczas współczynnik delta opcji sprzedaży z większą wartością parametru luki charakteryzuje się większą wrażliwością na zmianę ceny instrumentu bazowego. Jeżeli opcja jest nie-w-cenie, to większa wartość współczynnika gamma występuje w wypadku opcji odznaczającej się mniejszą wartością parametru luki.

\subsection{Współczynnik vega}

Współczynnik vega jest miarą wrażliwości, która określa wpływ wahań zmienności ceny instrumentu na cenę opcji. Wartości współczynnika vega zwykłej opcji sprzedaży są dodatnie. Wzrost/spadek zmienności ceny instrumentu bazowego wpływa na wzrost/spadek ceny opcji. Największą wartością współczynnika vega charakteryzują się opcje typu po-cenie. Wówczas cena opcji jest najbardziej wrażliwa na wahania zmienności ceny instrumentu bazowego. Wartości współczynnika vega opcji silnie-w-cenie oraz silne-nie-w-cenie zmierzają do zera.

Na rysunku 4 przedstawiono kształtowanie się wartości współczynnika vega rozpatrywanych opcji sprzedaży z odstępem. W tabeli 2 przedstawiono wpływ parametru luki oraz terminu wygaśnięcia na kształtowanie się wartości współczynnika vega opcji sprzedaży.

Rysunek 4. Kształtowanie się wartości współczynnika vega zwykłej opcji sprzedaży oraz opcji sprzedaży z odstępem

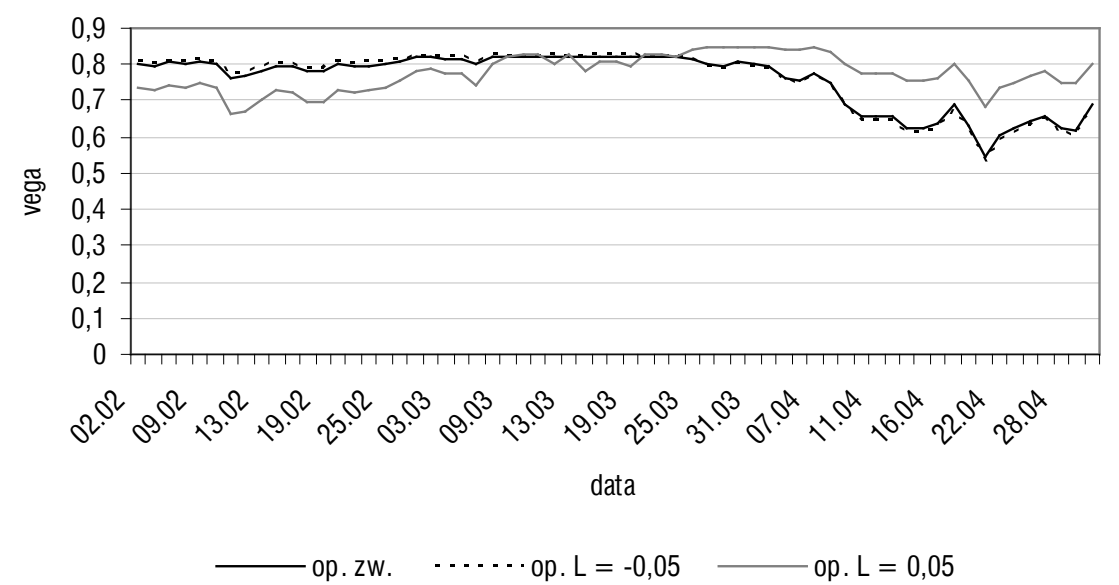

Źródło: Opracowanie na podstawie obliczeń własnych. 
Tabela 3. Wpływ parametru luki oraz terminu wygaśnięcia na wartość współczynnika vega opcji sprzedaży $z$ odstępem

\begin{tabular}{|c|c|c|c|c|}
\hline \multirow{2}{*}{ Wartość luki } & \multirow{2}{*}{$\begin{array}{l}\text { Czas wygaśnięcia } \\
\text { (w miesiącach) }\end{array}$} & \multicolumn{3}{|c|}{ Typ орсji } \\
\hline & & nie-w-cenie & po-cenie & w-cenie \\
\hline \multirow{3}{*}{$-0,05$} & 2 & 0,511 & 0,684 & 0,535 \\
\hline & 4 & 0,804 & 0,948 & 0,868 \\
\hline & 6 & 1,016 & 1,164 & 1,01 \\
\hline \multirow{3}{*}{0} & 2 & 0,497 & 0,672 & 0,547 \\
\hline & 4 & 0,791 & 0,934 & 0,875 \\
\hline & 6 & 1,003 & 1,15 & 1,072 \\
\hline \multirow{3}{*}{0,05} & 2 & 0,352 & 0,66 & 0,645 \\
\hline & 4 & 0,66 & 0,917 & 0,904 \\
\hline & 6 & 0,879 & 1,11 & 1,092 \\
\hline
\end{tabular}

Źródło: Obliczenia własne.

Wartości współczynnika vega opcji sprzedaży z odstępem odznaczają się następującymi własnościami:

- opcje nie-w-cenie lub po-cenie z większą wartością parametru luki charakteryzują się mniejszą wartością współczynnika vega, a zarazem mniejszą wrażliwością na wahania ceny instrumentu bazowego,

- jeśli cena instrumentu bazowego jest mniejsza od ceny wykonania, to wzrost wartości parametru luki wpływa na wzrost wartości współczynnika vega,

- największa wartość współczynnika vega występuje dla opcji po-cenie,

- zarówno dla dodatniej, jak i ujemnej wartości parametru luki wzrost terminu wygaśnięcia wpływa na wzrost wartości współczynnika vega, a tym samym na wzrost wrażliwości ceny opcji na wahania zmienności ceny instrumentu bazowego.

\subsection{Współczynnik theta}

Współczynnik theta określa zmianę ceny opcji, gdy długość okresu do terminu wygaśnięcia spadnie o jednostkę. Jeśli zwykła opcja sprzedaży jest typu silnie-w-cenie, to wartości współczynnika theta są dodatnie. Wówczas zbliżanie się terminu wygaśnięcia wpływa na spadek ceny opcji. W pozostałych wypadkach wartości współczynnika theta są ujemne. Oznacza to, że zbliżanie się terminu wygaśnięcia wpływa na spadek ceny opcji. Najbardziej wrażliwa na zmniejszanie się długości okresu do terminu wygaśnięcia jest cena opcji typu po-cenie. Wartości współczynnika theta opcji sprzedaży typu silnie-nie-w-cenie zmierzają do zera. 
Rysunek 5 jest ilustracją kształtowania się wartości współczynnika theta opcji sprzedaży z odstępem. W tabeli 4 przedstawiono wpływ parametru luki oraz terminu wygaśnięcia na wartość współczynnika theta opcji sprzedaży.

Rysunek 5. Kształtowanie się wartości współczynnika theta zwykłej opcji sprzedaży oraz opcji sprzedaży z odstępem

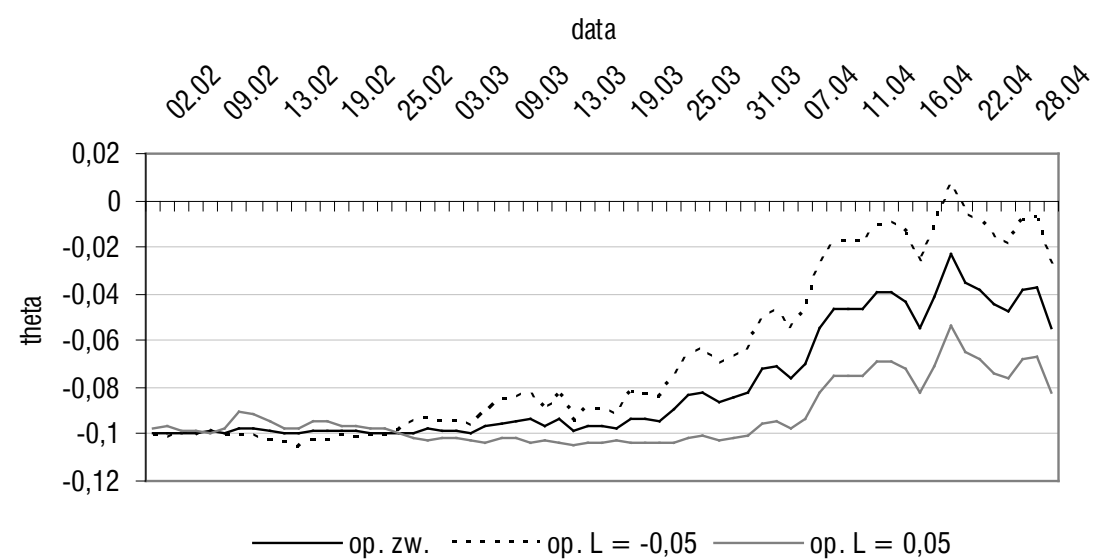

Źródło: Opracowanie na podstawie obliczeń własnych.

Tabela 4. Wpływ parametru luki oraz terminu wygaśnięcia na wartość współczynnika theta opcji sprzedaży $z$ odstępem

\begin{tabular}{|c|c|c|c|c|}
\hline \multirow{2}{*}{ Wartość luki } & \multirow{2}{*}{$\begin{array}{l}\text { Czas wygaśnięcia } \\
\text { (w miesiącach) }\end{array}$} & \multicolumn{3}{|c|}{ Тур орсјі } \\
\hline & & nie-w-cenie & po-cenie & w-cenie \\
\hline \multirow{3}{*}{$-0,05$} & 2 & $-0,1128$ & $-0,1226$ & $-0,0383$ \\
\hline & 4 & $-0,073$ & $-0,079$ & $-0,0361$ \\
\hline & 6 & $-0,061$ & $-0,065$ & $-0,0294$ \\
\hline \multirow{3}{*}{0} & 2 & $-0,1057$ & $-0,1281$ & $-0,0754$ \\
\hline & 4 & $-0,069$ & $-0,082$ & $-0,0543$ \\
\hline & 6 & $-0,0571$ & $-0,0681$ & $-0,041$ \\
\hline \multirow{3}{*}{0,05} & 2 & $-0,0787$ & $-0,1336$ & $-0,1155$ \\
\hline & 4 & $-0,0664$ & $-0,0886$ & $-0,0725$ \\
\hline & 6 & $-0,0521$ & $-0,0698$ & $-0,0526$ \\
\hline
\end{tabular}

Źródło: Obliczenia własne.

Zarówno dla dodatniej, jak i ujemnej wartości parametru luki najmniejsza wartość współczynnika theta występuje w wypadku opcji po-cenie. Dlatego cena tych opcji odznacza się największą wrażliwością na zmniejszanie się długości okresu do terminu wygaśnięcia. Wzrost wartości parametru luki przyczynia się do: 
- wzrostu wartości współczynnika theta opcji typu nie-w-cenie,

- spadku wartości współczynnika theta opcji po-cenie oraz $w$-cenie.

W wypadku analizowanych opcji wzrost terminu wygaśnięcia wpływa na wzrost wartości współczynnika theta, a tym samym na spadek wrażliwości ceny opcji na zbliżanie się terminu wygaśnięcia.

\subsection{Współczynnik rho}

Współczynnik rho wskazuje, o ile zmieni się cena opcji, gdy stopa procentowa aktywów wolnych od ryzyka zmieni się o jednostkę. Wartości współczynnika rho zwykłej opcji sprzedaży są ujemne. Wynika stąd, że wzrost/spadek stopy procentowej wpływa na spadek/wzrost ceny opcji. Wartości współczynnika rho opcji sprzedaży typu nie-w-cenie wzrastają do zera. Cena opcji sprzedaży silnie-nie-w-cenie w niewielkim stopniu zmienia się wraz z wahaniami stopy procentowej. Największe spadki wartości współczynnika rho występują w wypadku opcji w-cenie.

Na rysunku 6 zilustrowano kształtowanie się wartości współczynnika rho analizowanych opcji sprzedaży z odstępem ${ }^{9}$. W tabeli 5 przedstawiono wpływ parametru luki oraz terminu wygaśnięcia na wartość współczynnika rho opcji sprzedaży.

\section{Rysunek 6. Kształtowanie się wartości współczynnika rho zwykłej opcji sprzedaży} oraz opcji sprzedaży z odstępem

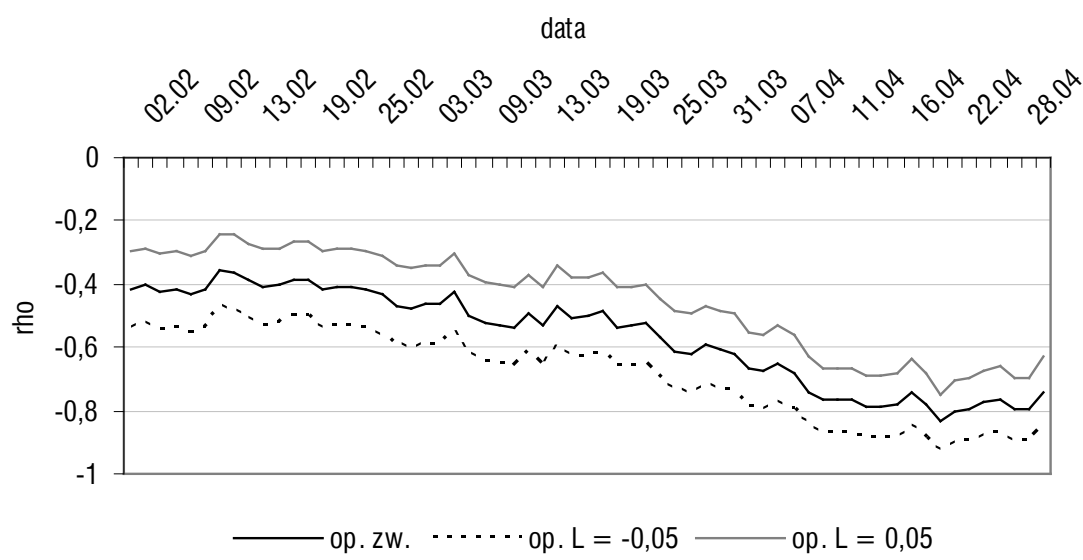

Źródło: Opracowanie na podstawie obliczeń własnych.

\footnotetext{
9 W wypadku analizowanych opcji walutowych rho jest miarą wrażliwości ceny opcji na zmianę krajowej stopy procentowej.
} 
Tabela 5. Wpływ parametru luki oraz terminu wygaśnięcia na wartość współczynnika rho opcji sprzedaży $z$ odstępem

\begin{tabular}{|c|c|c|c|c|}
\hline \multirow{2}{*}{ Wartość luki } & \multirow{2}{*}{$\begin{array}{c}\text { Czas wygaśnięcia } \\
\text { (w miesiącach) }\end{array}$} & \multicolumn{3}{|c|}{ Typ opcji } \\
\cline { 2 - 5 } & 2 & $-0,2232$ & $-0,4253$ & nie-w-cenie \\
\hline \multirow{3}{*}{0,05} & 4 & $-0,4924$ & $-0,771$ & $-0,5926$ \\
\cline { 2 - 5 } & 6 & $-0,7563$ & $-1,0858$ & $-1,0304$ \\
\cline { 2 - 5 } & 2 & $-0,1494$ & $-0,3241$ & $-1,413$ \\
\hline \multirow{3}{*}{0} & 4 & $-0,374$ & $-0,627$ & $-0,5072$ \\
\cline { 2 - 5 } & 6 & $-0,6048$ & $-0,9096$ & $-1,2383$ \\
\cline { 2 - 5 } & 2 & $-0,0756$ & $-0,222$ & $-0,4219$ \\
\hline \multirow{3}{*}{0,05} & 4 & $-0,255$ & $-0,4833$ & $-0,7561$ \\
\cline { 2 - 5 } & 6 & $-0,4534$ & $-0,7334$ & $-1,063$ \\
\hline
\end{tabular}

Źródło: Obliczenia własne.

Z analizy kształtowania się wartości współczynnika rho wynikają następujące własności:

- wzrost/spadek ceny instrumentu bazowego wpływa na wzrost/spadek wartości współczynnika rho opcji sprzedaży z odstępem,

- wzrost/spadek wartości parametru luki wpływa na wzrost/spadek wartości współczynnika rho,

- zarówno w wypadku dodatniej, jak i ujemnej wartości parametru luki, opcje z dłuższym terminem wygaśnięcia charakteryzują się mniejszą wartością współczynnika rho. Dlatego cena opcji sprzedaży z dłuższym terminem wygaśnięcia odznacza się większą wrażliwością na wahania stopy procentowej.

\section{Podsumowanie}

Modyfikacja funkcji wypłaty zwykłej opcji sprzedaży, która polega na wprowadzeniu parametru luki, w istotny sposób wpływa na cenę opcji oraz na możliwość otrzymanego dochodu z opcji. Opcja sprzedaży z dodatnim parametrem luki jest tańsza od zwykłej opcji sprzedaży. W związku z tym, zastosowanie jej w strategiach zabezpieczających może przyczynić się do obniżenia kosztów strategii zabezpieczających. Jednakże opcja ta gwarantuje mniejszą wypłatę. Dlatego w pewnych wypadkach można nie uzyskać efektywnego zabezpieczenia.

Wartość parametru luki w istotny sposób wpływa również na kształtowanie się wartości współczynników delta, gamma, vega, theta oraz rho. Wpływ parametru 
luki na wrażliwość ceny opcji na zmianę ceny instrumentu bazowego, zbliżanie się terminu wygaśnięcia, wahania zmienności ceny instrumentu bazowego oraz stopy procentowej wolnej od ryzyka zwiększają atrakcyjność opcji z odstępem w transakcjach spekulacyjnych. Uwzględniając oczekiwania związane z kształtowaniem się ceny instrumentu bazowego w przyszłości, wybór opcji z odpowiednim parametrem luki, ceną wykonania i terminem wygaśnięcia umożliwia konstruowanie różnych profili dochodu z zastosowanych transakcji spekulacyjnych.

\section{Bibliografia}

Dziawgo E., Modele kontraktów opcyjnych, Wydawnictwo Naukowe UMK, Toruń 2003.

Hull C.J., Options, futures and other derivatives, Prentice Hall International Inc., 2002.

Napiórkowski A., Charakterystyka, wycena i zastosowanie wybranych opcji egzotycznych, NBP Departament Analiz i Badań, Warszawa 2002.

Tarczyński W., Zwolankowski M., Inżynieria finansowa, Agencja Wydawnicza Placet, Warszawa 1999.

Willmot P., Derivatives. The Theory and Practice of Financial Engineering, John Wiley \& Sons, Chichester 2000.

Zhang P.G., Exotic Options. A Guide to Second Generation Options, Word Scientific, Singapore 2001.

\section{Influence of the Gap Parameter on the Risk of the Put Options}

Gap options are singular payoffs options characterized by discontinuity of pay-off function. The article presents the properties of the gap put option: construction of instrument, the pay-off function, the pricing model, the influence of selected factors on the pricing and the value measurements of risk (coefficients delta, gamma, vega, theta, rho). The paper analyses the influence of the underlying instrument's price, the time maturity and the gap parameter on the risk performance of the put options using pricing simulations of the currency options on EUR/PLN.

Keywords: put option, derivatives 


\section{L'influence du paramètre d'écart (gap parameter) sur le risque des options de vente}

L'article présente les caractéristiques des options de vente appelées "gap options»: la construction de l'instrument, la fonction de pay-off, le modèle de valorisation, l'influence de certains facteurs sur le prix et les mesures de valeur de risque (coefficients delta, gamma, vega, thêta, rho). Cet article vise à analyser l'impact du paramètre d'écart, du prix d'un instrument financier principal et du délai d'expiration sur le risque des options de vente. L'auteur se réfère aux simulations d'évaluation des options de change EUR/PLN.

Mots-clés: les option de vente, les dérivés

\section{Влияние параметра щели на риск при опционе на продажу}

Gap-опционы принадлежат к рау-off опционам, которые характеризуются разрывной платежной функцией. Статья представляет свойства gар-опционов: особенности инструмента, платежную функцию, модель ценообразования, влияние избранных факторов на цену опциона и показатели риска (коэффициенты дельта, гамма, вега, тета, ро). Целью работы является анализ влияния цены базового инструмента, времени до погашения и параметра щели на риск, связанный с опционом на продажу. В исследовании была проведена симуляция образования цен валютных опционов (валютная пара EUR / PLN).

Ключевые слова: пут-опцион, деривативы 
